\title{
Seasonal phytoplankton nutrient limitation patterns as revealed by bioassays over Baltic Sea gradients of salinity and eutrophication
}

\author{
Timo Tamminen ${ }^{1, *}$, Tom Andersen ${ }^{2}$ \\ ${ }^{1}$ Finnish Environment Institute (SYKE), PO Box 140, 00251 Helsinki, Finland \\ ${ }^{2}$ Department of Biology, University of Oslo, PO Box 1066, Blindern, 0316 Oslo, Norway
}

\begin{abstract}
The in situ P versus N limitation of northern Baltic Sea phytoplankton was studied over 3 seasonal cycles at 6 locations, encompassing the large-scale salinity and eutrophy gradients of the Baltic Sea. Limitation patterns were inferred from 170 time-series $(3 \mathrm{~d})$ experiments with a replicated factorial experimental design, analyzed using a novel model selection-based classification. Seven limitation classes describe exclusive and primary limitation by $\mathrm{N}, \mathrm{P}$, combined $\mathrm{N}$ and $\mathrm{P}$, or none. Response parameters were chlorophyll $a(\mathrm{chl} a)$ and primary productivity. Although $\mathrm{chl} a$ responses reported more $\mathrm{N}$-limited, and ${ }^{14} \mathrm{C}$ responses more $\mathrm{P}$-limited cases, the responses of both parameters were highly similar. Distinct seasonal patterns of in situ P versus N limitation were evident, reproducible, and dissimilar even in closely related environments. The most pristine low-saline areas were dominantly P-limited, while more eutrophied areas showed predominant N limitation even at comparable salinities. The typical Baltic Sea surface salinity regions (5 to 6 PSU) were clearly N-limited either for summer months (e.g. the mildly eutrophied Bothnian Sea), or throughout the growth season (e.g. the eutrophied Gulf of Finland), although terrestrial loading ratios for the Baltic Sea exceed the Redfield ratio several-fold. The commonly vigorous $\mathrm{N}_{2}$-fixing cyanobacterial blooms in the southern basins do not alleviate the basic N-limitation pattern, and do not appear in the summertime Nlimited Bothnian Sea. Management strategies should include toning down the N-limited spring bloom in eutrophied areas, which fuels summertime P release from sediments, in turn favoring cyanobacteria. Terrestrial nutrient loading does not reach offshore areas without significant modification and loss, emphasizing the role of coastal zones in global nutrient cycles and stoichiometry.
\end{abstract}

KEY WORDS: Nutrient limitation · Coastal eutrophication · Bioassays $\cdot$ Phytoplankton · Nitrogen · Phosphorus · Baltic Sea

\section{INTRODUCTION}

Nutrient limitation is one of the perennial topics in the limnological research tradition, and among those with the most obvious connection to the environmental management of water bodies. Without knowledge of the limiting factors of aquatic primary production, interventions to eutrophication caused by anthropogenic nutrient discharges are at best haphazard and ineffective, and at worst counter-effective. The paradigm of P limitation in freshwater ecosystems, based especially on the cornerstone works of Vollenweider
(1968, 1976) and Schindler (1974, 1977), has been repeatedly supported directly by experiments and indirectly by relative nutrient availability analyses. During the last decades, the picture has somewhat diversified and $\mathrm{N}$ limitation appears to be more common in freshwater systems than was previously considered (Morris \& Lewis 1988, Elser et al. 1990).

Marine research on nutrients has, contrary to lake studies, largely concentrated on N (Hecky \& Kilham 1988, Howarth 1988, National Research Council 2000) since the early work by Ryther \& Dunstan (1971); with some notable exceptions such as P limitation in the 
Mediterranean Sea (Thingstad et al. 2005). Eutrophication problems in coastal systems have developed far later than in lakes, and consequently the nutrient limitation data available from saline environments are, although accumulating, still sparse compared to the limnological data (Cloern 2001). In addition to its importance in coastal eutrophication management, marine phytoplankton nutrient limitation has recently become a central issue in studies of global biogeochemical nutrient cycles and ecological stoichiometry of the oceans (Arrigo 2005).

Nutrient limitation relates to the immediate time scales of planktonic primary production in the euphotic surface layer. However, the underlying driving forces behind the in situ conditions span larger biogeochemical temporal and spatial scales, involving not only whole water bodies but also processes extending far up into terrestrial catchments. Despite the obvious and challenging multidimensionality of drivers, including both anthropogenic and natural nutrient sources and losses, it is fair to conclude that an essential component of any analysis of nutrient limitation of a particular aquatic system should be the verification of nutrient limitation at the focal point of action, in situ planktonic primary production.

Methods for verifying the limitation pattern of this domain all carry inherent constraints, which also relate to the temporal and spatial scales of the processes involved (e.g. Beardall et al. 2001). Limitation by a particular nutrient and its availability should be closely knit aspects of nutrient cycles in any system. It is therefore conceivable that sufficiently imbalanced availability of main nutrients would provide enough information on the nutrient limitation patterns to allow us to infer these from hierarchically distant properties of the system, such as large-scale nutrient budgets, nutrient loading ratios, or pool sizes of inorganic nutrients. In several cases, however, this nutrient limitation information is either not readily available, or it appears inconclusive due to the apparently low availability of more than one potentially limiting resource. It is in this situation that methods for directly assessing in situ nutrient limitation of phytoplankton should be evaluated for their strengths and constraints.

It is not immediately apparent how salinity as such produces the dichotomy between the key nutrients in freshwater and marine environments. Terrestrial nutrient runoff to the coastal zone is characterized by a surplus of nitrogen both globally (Seitzinger et al. 2002, Harrison et al. 2005), and often the more so in coastal areas under strong anthropogenic pressure, like the Baltic Sea (terrestrial loading ratio being ca. triple the Redfield ratio; Stålnacke et al. 1999, HELCOM 2004). This is affected by riverine inputs flowing from P-limited freshwater domains or point sources with efficient
P removal established. Despite the $\mathrm{N}$ surplus in nutrient loading, productive surface layers of the coastal recipients tend to converge towards the Redfield ratio benchmarking average phytoplankton nutrient demands, and often even below that ratio (e.g. Fisher et al. 1992, 1999, Pitkänen \& Tamminen 1995). Modification of nutrient pools in the brackish transition zone must therefore be substantial.

A common rationale for different roles of $\mathrm{P}$ and $\mathrm{N}$ in different salinity regimes has been the general absence of marine phytoplankton species capable of fixing atmospheric $\mathrm{N}_{2}$ (with the notable offshore exception of Trichodesmium spp.), while there are a considerable number of freshwater cyanobacteria sharing this N flow shortcut (Howarth 1988, Vitousek \& Howarth 1991). Another specific N pathway working towards the same outcome is loss through denitrification, which is suggested to be more efficient in shallow coastal regions compared to freshwater habitats (Nixon 1981, Seitzinger 1988). However, salinity also directly affects the relative availabilities of inorganic $P$ and $\mathrm{N}$ through bottom water and sediment chemistry, as a major component of marine salt, sulfate, plays a key role in sequestering iron and thus weakening the permanent removal of inorganic $P$ from the water column by iron precipitation, which is a central mechanism maintaining $\mathrm{P}$ limitation in freshwater (Caraco et al. 1989, 1990, Blomqvist et al. 2004). Several biogeochemical processes thus jointly affect the N:P availability transition along the salinity gradient, amounting to more effective removal of $\mathrm{N}$ from, and/or more effective retention of $\mathrm{P}$ in the productive surface layer of the system.

Each of these processes operates on a characteristic time scale, and the appropriate time scale to use for estimating nutrient limitation along the gradient is not always obvious, especially with environmental management interests in mind. The essentially instantaneous assessment of phytoplankton nutrient limitation, based on physiological indices like cellular composition or those obtained by fast repetition rate fluorometry (see Beardall et al. 2001), describes preconditions for primary production. However, linkages between the physiological state of cells, or short-term photochemical responses, and long-term biomass accumulation are often far from obvious. Physiological nutrient limitation of instantaneous phytoplankton growth is also, from the eutrophication control point of view, less central than limitation manifested in biomass changes, as most of the negative eutrophication effects are connected to the fate of the increased phytoplankton biomass.

Changes of autotroph biomass in bioassays of various kinds, all sharing the traditional Liebigian concept of treatments with alternative nutrient combinations in order to increase the carrying capacity and thus iden- 
tify which nutrient is lacking, allow for the estimation of the limiting nutrient it seems, without dispute. Growth and biomass accumulation are, however, outcomes of processes operating on several scales, the more so if the test target is a natural planktonic community where the batch culture analogy has obvious limitations. Nutrient addition may stimulate autotroph growth (thus indicating limitation by that particular nutrient) without any concomitant biomass increase, either because the increased production is efficiently harvested by secondary producers (Kivi et al. 1993), or because stimulation of one species may suppress another species not limited by the same nutrient.

Leaving in situ food web interactions aside would clearly diminish the naturalness and thus the applicability of the results. Short-term bioassays with the natural planktonic community thus reflect the nutrient limitation of the ambient phytoplankton, but the signal is potentially modified by prevailing trophic interactions within the community, as would happen in the open system under study within time scales compatible with algal growth response.

We studied the in situ nutrient limitation patterns of one of the largest estuarine areas of the world, the Baltic Sea. This northern European non-tidal environment hosts exceptionally extensive and relatively stable gradients of low-end salinities, where the coastal shifts in $\mathrm{P}$ to $\mathrm{N}$ limitation predicted by current thinking should take place. The northern basins (Gulf of Bothnia and Gulf of Finland) have distinct salinity gradients but also exhibit large differences in the levels of eutrophication due to terrestrial nutrient sources, to the extent that the Gulf of Finland is one of the most eutrophied major estuarine areas, whereas the Gulf of Bothnia remains relatively pristine (Larsson et al. 1985, Stålnacke et al. 1999, HELCOM 2002). Growth season concentrations of both inorganic $\mathrm{P}$ and $\mathrm{N}$ are generally low, often close to or even below the detection limits of standard analyses, so that assessment of the limiting nutrient on the basis of monitoring nutrient data is uncertain. The Baltic Sea is also one of the few major estuaries in the world where $\mathrm{N}_{2}$-fixing cyanobacteria appear in significant quantities during the late growth season (Kahru et al. 1994, Larsson et al. 2001). The Baltic coastal gradients therefore provide an exceptionally suitable testing ground for experimental in situ nutrient limitation assessment.

We chose to study the in situ limitation patterns by running $3 \mathrm{~d}$ time series bioassays with natural planktonic communities, with daily sampling under controlled laboratory conditions simulating the in situ annual development of temperature and light-dark cycles. Six coastal locations distributed along $1000 \mathrm{~km}$ of the Finnish coastline were selected to represent the large-scale coastal gradients, and the bioassays were repeated ca. 10 times annually for 3 growth seasons at each location, producing 170 bioassays in total. In this paper we describe the phytoplankton responses as measured by chl $a$ and primary productivity. The amount of data (>8000 chl a measurements and $>5000$ primary productivity measurements) from exactly comparable experiments, with both measurement- and treatment-level replication, both necessitated and allowed for the development of strict quality control routines, which were developed after the analysis of the statistical properties of the data (Appendix 1; available at www.int-res.com/articles/ suppl/m340p121_app.pdf). Statistical modeling of nutrient enrichment responses was based on a novel model selection-based classification described in full detail in Andersen et al. (2007). This method allowed quantitative assessment of temporal and spatial in situ limitation patterns.

The implications of in situ limitation patterns for environmental management is discussed in the context of seasonal biogeochemical cycles of the coastal environment. Detailed analysis of the relations between the observed in situ limitation and other environmental data, like basin-scale nutrient stoichiometry and longterm trends, will remain the topics of separate studies in preparation.

\section{MATERIALS AND METHODS}

Sampling program and organization. The data originate from a 3 yr study carried out during the seasonal growth periods of years 1992 to 1994 at 6 sampling stations (Fig. 1, see coordinates in Table 1) distributed along the entire Finnish coastline of the Baltic Sea (ca. $1000 \mathrm{~km}$ ). Stations were selected to be representative of the major sub-basins of the northern Baltic Sea, and for their location in the vicinity of a laboratory of the network of the Finnish environmental administration (the laboratories of the Water and Environment Districts of Oulu, Kokkola, Vaasa, Turku, Helsinki and Kymi). During each study year, stations were visited 7 to 12 times, yielding 24 to 30 experiments per location during the whole study period, and a total of 170 experiments (Table 1). A combined 501 sample was taken from the euphotic surface layer by pooling casts taken at $1 \mathrm{~m}$ intervals down to twice the Secchi depth. The pooled sample was taken to the laboratory in two 301 polyethylene carboys and stored overnight in the dark in a thermostated water bath adjusted to the in situ surface temperature. No prescreening was applied, and the experiment was started the following morning according to the experimental design presented below. Incubations and sample preparations were done at the site, and sampling took place accord- 


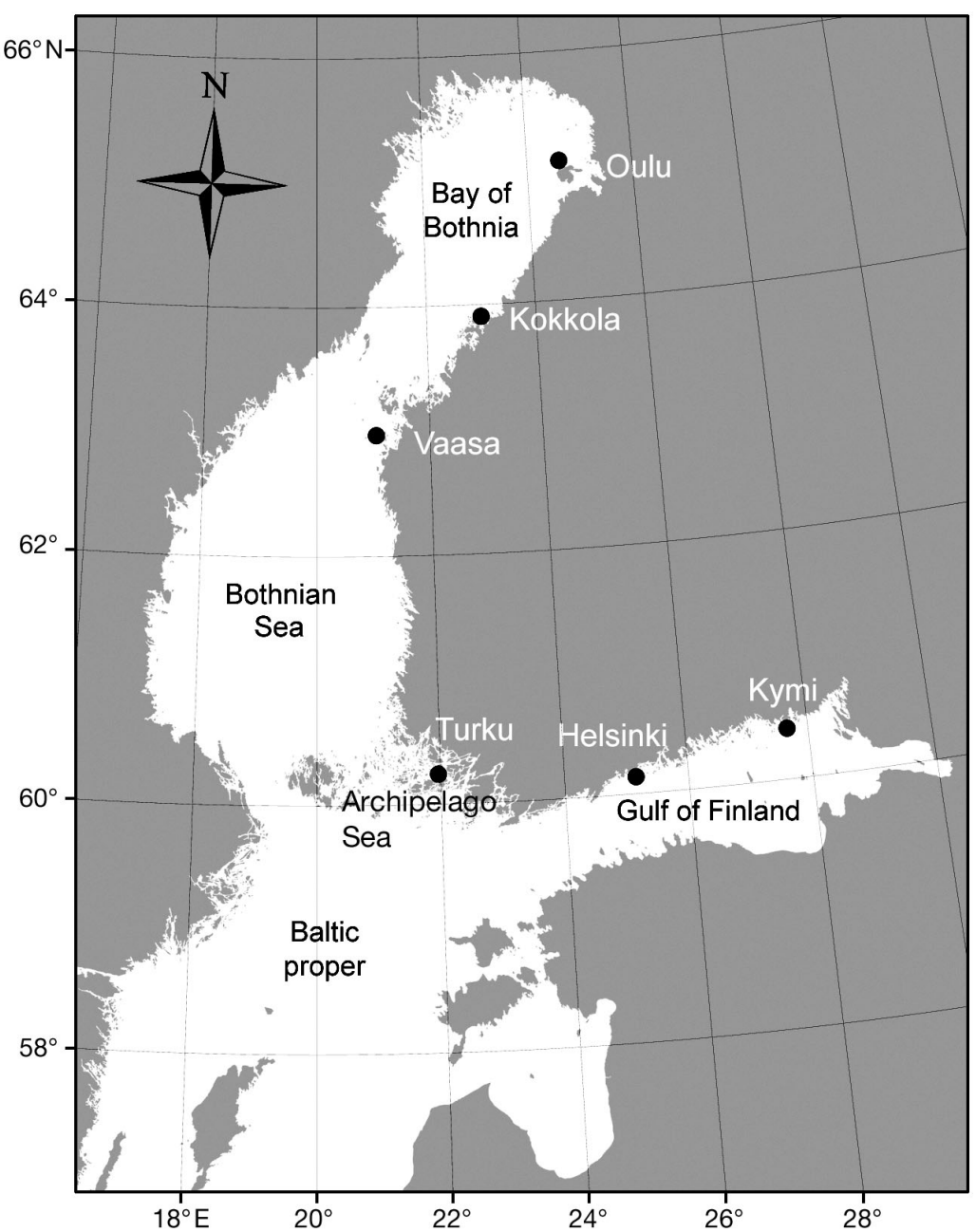

Fig. 1. Study area, showing the location of the 6 sampling stations along the Finnish coastline of the Baltic Sea. For the precise coordinates of the sampling stations, see Table 1

ing to a fixed weekly program, with little variability (within ca. $1 \mathrm{~h}$ ) in the timing of daily sampling $(09: 00 \mathrm{~h}$ ) and the subsequent incubations and sample preparations. Preserved samples were shipped to the laboratory of the Tvärminne Zoological Station (University of Helsinki) for measurement.
Experiment design and measurements. Each experiment consisted of 8 experimental units (1 unit $=61$ water in an 81 polycarbonate bottle) that were filled from the carefully stirred water sample and manipulated with phosphate $\left(20 \mu \mathrm{gP} \mathrm{l}^{-1}\right)$ and/or ammonium $\left(80 \mu \mathrm{g} \mathrm{N} \mathrm{l}^{-1}\right)$ additions according to a $2^{2}$ factorial design with replicates (see Fig. 2). All experiments were carried out at in situ temperature (thermostated water bath) under the locally prevailing lightdark cycles of the experimental week, with daylight-spectrum fluorescent tubes (Philips TLD 965) producing an irradiance of 100 $\mu \mathrm{mol}$ quanta $\mathrm{m}^{-2} \mathrm{~s}^{-1}$ inside the polycarbonate bottles. The bottles were gently shaken twice a day during the experiment, otherwise no mixing was performed. Samples for time-zero measurement of chl $a$ and ${ }^{14} \mathrm{C}$ uptake were taken only from unmanipulated water, while all experimental units were sampled for chl a on Days 1 to 3 and ${ }^{14} \mathrm{C}$-uptake on Days 1 and 2. Parameters were measured in duplicate, giving a total of $50 \mathrm{chl}$ a samples and $34{ }^{14} \mathrm{C}$ samples from each experiment. A total of 170 experiments were performed over the $3 \mathrm{yr}$ period, of which 2 were lost entirely due to mistakes in the nutrient additions at the start. A reasonably small number of analytical errors at some stage of the procedure reduced the data pool slightly, and after final quality control routines (see description in Appendix 1), ca. $95 \%$ of the data for both parameters remained for further analysis. As the lacking or discarded data for these parameters were non-overlapping, a total of 154 experiments (91\%) produced a full set of both parameters.

Chl a was measured fluorometrically (Shimadzu RF5000) with pure chl a (Sigma) as standards. Samples were prepared in duplicate by filtering $100 \mathrm{ml}$ subsamples onto Whatman GF/F glass-fiber filters, which

Table 1. Sampling stations and no. of experiments made annually. Station names used here correspond to the location of the laboratory of the respective Finnish Water and Environment District. Stations are characterized by the average values of salinity, total $\mathrm{N}$, total $\mathrm{P}$ and chl $\mathrm{a}$ of the initial sample for the experiments of the study period ( $\mathrm{n}=24$ to 30 )

\begin{tabular}{|c|c|c|c|c|c|c|c|c|c|c|}
\hline Station & $\begin{array}{l}\text { Depth } \\
\text { (m) }\end{array}$ & $\begin{array}{l}\text { Latitude } \\
\left({ }^{\circ} \mathrm{N}\right)\end{array}$ & $\begin{array}{l}\text { Longitude } \\
\qquad\left({ }^{\circ} \mathrm{E}\right)\end{array}$ & $\begin{array}{l}\text { Salinity } \\
\text { (PSU) }\end{array}$ & $\begin{array}{c}\text { Total N } \\
\left(\mu g \mathrm{~N} \mathrm{l}^{-1}\right)\end{array}$ & $\begin{array}{l}\text { Total P } \\
\left(\mu g \mathrm{P}^{-1}\right)\end{array}$ & $\begin{array}{c}\operatorname{chl} a \\
\left(\mu \mathrm{g} \mathrm{l}^{-1}\right)\end{array}$ & 1992 & $\begin{array}{l}\text { riments (n) - } \\
1993\end{array}$ & 1994 \\
\hline Oulu & 24 & 65.1333 & 24.6000 & 2.5 & 269 & 8 & 3.0 & 7 & 9 & 8 \\
\hline Kokkola & 19 & 63.9186 & 22.9840 & 3.3 & 323 & 12 & 7.0 & 7 & 11 & 12 \\
\hline Vaasa & 18 & 62.9848 & 21.0368 & 5.1 & 269 & 13 & 3.3 & 7 & 12 & 10 \\
\hline Turku & 51 & 60.2555 & 21.9566 & 6.0 & 359 & 18 & 4.7 & 9 & 11 & 10 \\
\hline Helsinki & 33 & 60.1495 & 25.1442 & 5.1 & 420 & 27 & 10.3 & 9 & 11 & 10 \\
\hline Kymi & 48 & 60.4201 & 27.6520 & 3.6 & 389 & 23 & 10.3 & 7 & 10 & 10 \\
\hline
\end{tabular}




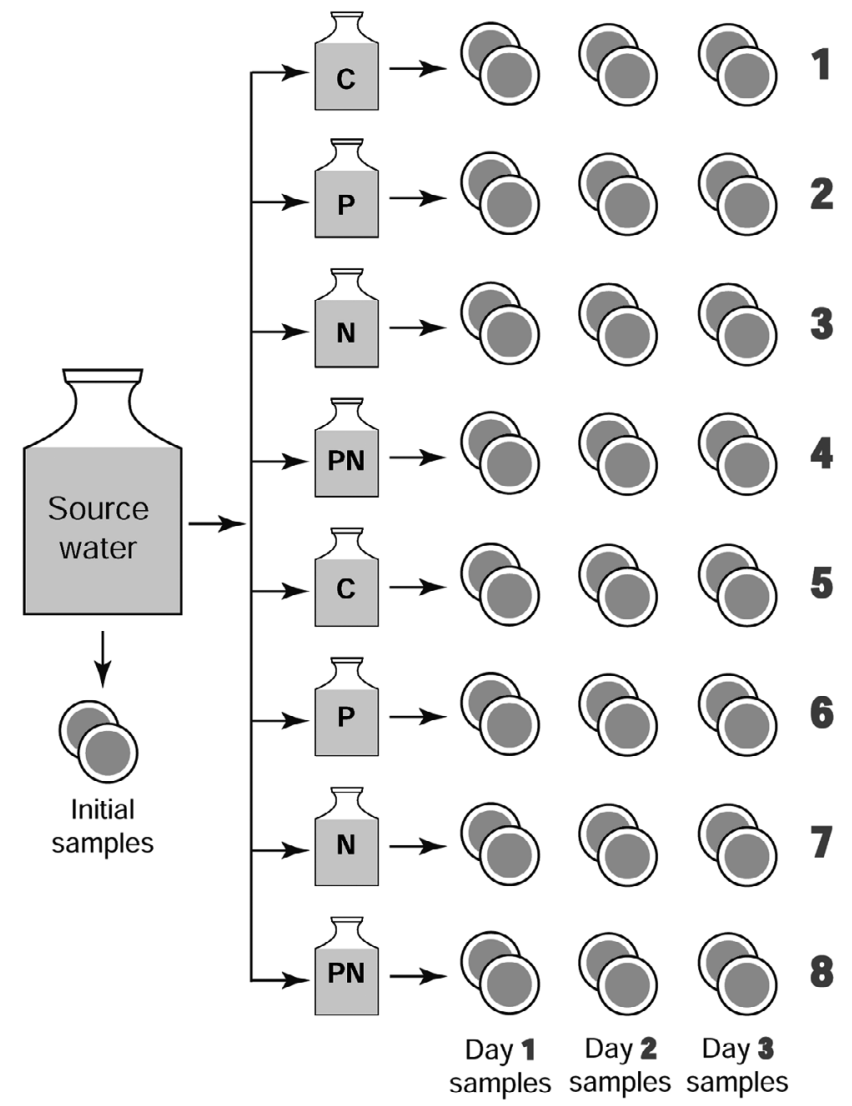

Fig. 2. Basic experimental design (replicated $2^{2}$ factorial designs) and sampling scheme for 3 repeated observations of chl $a$ response. Treatment codes: $\mathrm{C}=$ control (no nutrient addition), $\mathrm{P}=20 \mu \mathrm{m} \mathrm{P} \mathrm{l^{-1 }}, \mathrm{N}=80 \mu \mathrm{g} \mathrm{N} \mathrm{l^{-1 }}, \mathrm{PN}=$ combined $\mathrm{P}+\mathrm{N}$ addition

were deep-frozen in scintillation vials until analysis. Samples were extracted in $94 \%$ ethanol for $24 \mathrm{~h}$ in the dark at room temperature prior to measurement. Primary productivity was measured using the ${ }^{14} \mathrm{C}$ technique, by preparing dark and duplicate light subsamples for each sample. Incubation took place in the thermostated water bath at the same irradiance as the experimental units, in $20 \mathrm{ml}$ acid-washed and precombusted $\left(450^{\circ} \mathrm{C}\right)$ glass scintillation vials after adding $100 \mu \mathrm{l}$ of $20 \mu \mathrm{Ci} \mathrm{ml}^{-1}$ bicarbonate (Amersham). Incubations were terminated after 2 to $4 \mathrm{~h}$ by adding $200 \mu \mathrm{l}$ of $38 \%$ formaldehyde. After transportation to the Tvärminne laboratory, a $4 \mathrm{ml}$ subsample was acidified in a ventilation cupboard by adding $100 \mu \mathrm{l}$ of $1 \mathrm{~N} \mathrm{HCl}$. After $24 \mathrm{~h}, 7 \mathrm{ml}$ of scintillation cocktail (Hi-Safe 3) was added and the radioactivity was measured with a Wallac Rack-Beta scintillation counter with the external standard channel ratio method.

Statistical modeling of nutrient addition responses. The statistical properties of the data, preconditions for the modeling of responses, and quality control procedures are summarized in Appendix 1 (available at www.int-res.com/articles/suppl/m340p121_app.pdf). The statistical treatment is based on a novel model selection procedure for unsupervised classification of nutrient limitation bioassays (see Andersen et al. 2006 for a detailed description). Briefly, the method defines a set of a priori treatment contrast structures, or nutrient limitation classes, which can be given direct biological interpretations. Combining treatment contrast structures and time effects (represented by orthogonal polynomials) results in a set of linear models, from which a 'best' model can be selected through confrontation with data. The model selection is based on minimizing the Akaike Information Criterion (AIC) which depends on both the goodness of fit and the complexity of a model (the principle of parsimony). The treatment contrast structure of the selected 'best' model (the one with the lowest AIC) for a particular set of experimental data will thus implicitly yield its nutrient limitation class. The following 7 nutrient limitation classes were used (with their abbreviations):

(1) No response (00): No effect upon nutrient addition: all 4 treatments behave identically, even though their common time course can be highly non-linear (up to 3rd order polynomial). Typically observed when both inorganic nutrients are abundant during offseason or phytoplankton growth is constrained by low temperatures or extreme turbidity, or strongly controlled by grazers.

(2) Exclusive P limitation (XP): The supply of $\mathrm{N}$ is so much in excess of demand that adding it has no effect. The $\mathrm{N}$ alone treatment behaves identically to the control, and the $\mathrm{P}$ alone treatment is indistinguishable from the PN treatment.

(3) Primary P limitation (P1): The supply of $\mathrm{N}$ is sufficient for the $\mathrm{N}$ alone and control treatments to behave identically, but addition of $\mathrm{P}$ alone will soon lead to $\mathrm{N}$ deficiency. Thus the $\mathrm{P}$ alone treatment will not behave identically to the PN treatment.

(4) Exclusive combined limitation (XC): The supplies of $\mathrm{P}$ and $\mathrm{N}$ are closely balanced to the demands, so that neither the $\mathrm{P}$ alone nor the $\mathrm{N}$ alone treatments will behave differently from the control. Only the combined addition of $\mathrm{P}$ and $\mathrm{N}$ will produce a response, which will be different from the 3 other treatments.

(5) Primary combined limitation (C1): All addition treatments behave differently from each other and from the control. Combined $\mathrm{P}$ and $\mathrm{N}$ additions have effects on the phytoplankton community, but in contrast to the $\mathrm{XC}$ class, $\mathrm{P}$ and $\mathrm{N}$ have effects also as single additions.

(6) Primary N limitation (N1): The supply of P is sufficient for the $\mathrm{P}$ alone and control treatments to behave identically, but addition of $\mathrm{N}$ alone will soon lead to $\mathrm{P}$ deficiency. Thus the $\mathrm{N}$ alone treatment will not behave identically to the PN treatment. 
(7) Exclusive $\mathrm{N}$ limitation (XN): The supply of P is so much in excess of demand that adding it has no effect. The $\mathrm{P}$ alone treatment behaves identically to the control, and the $\mathrm{N}$ alone treatment is indistinguishable from the PN treatment.

The primary combined (C1) pattern can occur if different components of the planktonic community (e.g. different phytoplankton species, or phytoplankton versus bacterioplankton) are limited by different nutrients. The C1 category would also include apparent nonsense results that have a completely unrelated set of responses to manipulations, such as single nutrient responses exceeding the combined $\mathrm{PN}$ response, or the control exceeding nutrient additions. However, the majority of responses falling into this category in the present data showed single $\mathrm{P}$ and $\mathrm{N}$ responses enveloped by the PN addition and control. For the sake of keeping the classification scheme as simple as possible, no further classes were introduced.

The experimental design includes an extra level of replication since duplicate samples were taken from each experimental unit. This replication is valuable for measurement of quality control, as well as for safeguarding against accidentally lost measurements and obvious outliers. In order not to inflate the degrees of freedom, the model fitting was based on the means of the unitlevel replicates. We also did bootstrap analyses in which we generated input data to the classification procedure through random selection among the unit-level replicates. Since there are 25 duplicated chlorophyll measurements in a single experiment, there are $2^{25}=$ 33554432 possible ways to do this. If this is repeated many times (1000 in our case), the resulting frequency distribution of limitation classes will give an indication of classification uncertainty due to measurement noise.

It should be noted that this bootstrapping procedure does not include all sources of error, and will give an optimistic estimate of the ambiguity of the classification. On the other hand, Table 2 shows that betweenunit measurement noise is actually of the same order as the within-unit measurement noise in the present data set, so our bootstrap analysis should yield some important insights into the robustness of the experiment classification.

\section{RESULTS}

\section{Seasonal succession of initial conditions}

The geographical differences in the initial conditions for the experiments are summarized in Fig. 3 for inorganic $\mathrm{P}$ and $\mathrm{N}$, together with chl a. The northernmost basin (Bay of Bothnia; stations Oulu and Kokkola) displayed a pattern for inorganic $\mathrm{N}$ that differed from the
Table 2. Coefficients of variation between replicate samples $\left(\omega_{R}\right)$ and between replicate treatments in different laboratories $\left(\omega_{G}\right)$ for ${ }^{14} \mathrm{C}$-uptake and chl a samples

\begin{tabular}{|lccccc|}
\hline \multirow{2}{*}{ Laboratory } & \multicolumn{2}{c}{${ }^{14} \mathrm{C}$} & & \multicolumn{2}{c|}{ Chl $a-$} \\
\cline { 2 - 3 } & $\begin{array}{c}\text { Sample } \\
\omega_{R}(\%)\end{array}$ & $\begin{array}{c}\text { Treatment } \\
\omega_{G}(\%)\end{array}$ & & $\begin{array}{c}\text { Sample } \\
\omega_{R}(\%)\end{array}$ & $\begin{array}{c}\text { Treatment } \\
\omega_{G}(\%)\end{array}$ \\
\hline 1 & 4.7 & 6.5 & & 4.9 & 5.0 \\
2 & 4.2 & 5.4 & & 5.3 & 5.8 \\
3 & 6.2 & 6.5 & & 6.0 & 4.8 \\
4 & 5.6 & 5.9 & & 5.2 & 6.0 \\
5 & 5.5 & 7.1 & & 5.9 & 7.0 \\
6 & 6.6 & 9.4 & 7.7 & 8.6 \\
\hline
\end{tabular}

other basins, with late and only partial depletion of the wintertime dissolved inorganic nitrogen (DIN) storage during the late, and modest, spring bloom. Although both northernmost stations showed some summertime samplings with almost entirely depleted DIN, reaccumulation had already started during late summer. Dissolved inorganic phosphorus (DIP) remained low throughout the season, often below the detection limit of standard monitoring programs $\left(<2 \mu \mathrm{gP} \mathrm{l}^{-1}\right)$. Dissolved silicate (DSi) was abundant through the years in the northern basin (data not shown).

At the other locations, experiments started from late spring bloom stages, with inorganic nutrients already depleted, and decreasing chl a values (Fig 3). Summertime concentrations of both inorganic $\mathrm{P}$ and $\mathrm{N}$ were generally low, close to or below standard detection limits, making it difficult to infer phytoplankton limitation with any certainty from the concentration data only (note in Fig. 3 the scaling of DIN and DIP panels in Redfield weight ratio $\mathrm{N}: \mathrm{P}=7.2$ ). Silicate might potentially limit diatom growth during the late spring bloom in the southern basins, as occa-

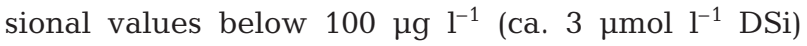
were recorded (data not shown). However, the phytoplankton communities responded to experimental $\mathrm{N}$ and $\mathrm{P}$ additions, indicating that lack of silicate did not play a major role in their growth limitation.

\section{Temporal development of responses at different locations}

The contrast-based classification method can be used to compute the relative distribution of responses to nutrient addition among different stations along the coastal gradient from the northernmost Bay of Bothnia to the easternmost Gulf of Finland. Such distributions can be based on either of the 2 response parameters and any particular day of the experiment (Days 1 and 2 for ${ }^{14} \mathrm{C}$-uptake and Days 1 to 3 for chl a). Fig. 4 summarizes location-wise (geographical gradient $\mathrm{N}$ to $\mathrm{S}$, then 

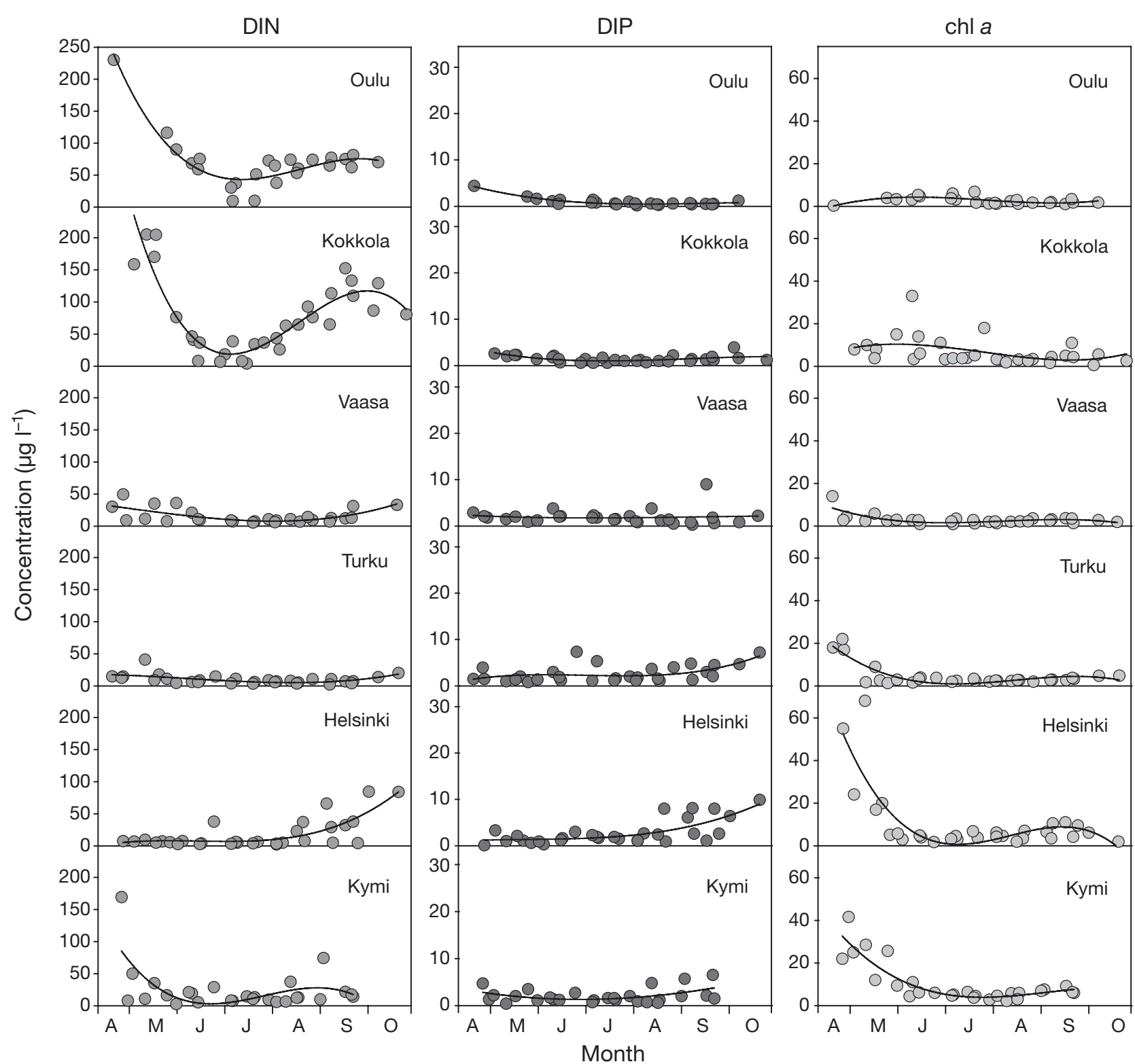

Fig. 3. Seasonal succession of the initial conditions (dissolved inorganic nitrogen [DIN] $=$ inorganic $\mathrm{N}^{-}$as the sum of $\mathrm{NO}_{3}{ }^{-}$and $\mathrm{NH}_{4}{ }^{+}$; Dissolved inorganic phosphorus [DIP] $=\mathrm{PO}_{4}{ }^{3-}$ ) for the 170 experiments conducted at the 6 stations (see Fig. 1 for their locations). All concentrations in weight units $\left(\mu \mathrm{g} \mathrm{l} \mathrm{l}^{-1}\right)$. The 3 years of the study are pooled on a joint seasonal axis. Note: DIN and DIP panels are scaled to the Redfield weight ratio N:P $=7.2$. Thin black line $=$ nonlinear regression (polynomic; cubic) with dynamic fitting

to E running in each panel from left to right, see also Fig. 1) the temporal development of both response parameters, revealing several interesting patterns with respect to location, parameter, and duration of the experiment.

The most obvious pattern in Fig. 4 is the shift in $\mathrm{P}$ limitation dominance in the northernmost stations (Bay of Bothnia locations Oulu and Kokkola) to N limitation dominance in the south (Gulf of Finland locations Helsinki and Kymi), with the intermediate locations (Bothnian Sea and Archipelago Sea locations
Vaasa and Turku) strongly resembling the latter. It also appears that there are minor, but consistent differences in classifications based on different parameters, in the sense that ${ }^{14} \mathrm{C}$-uptake based classifications tend to give more cases of P limitation, while chl a based classifications tend to produce more cases of $\mathrm{N}$ limitation.

The primary productivity responses (Fig. 4, first row panels) developed faster than chl a responses (Fig. 4, second row panels) in the sense that the share of noresponse experiments (the difference between 1 and 


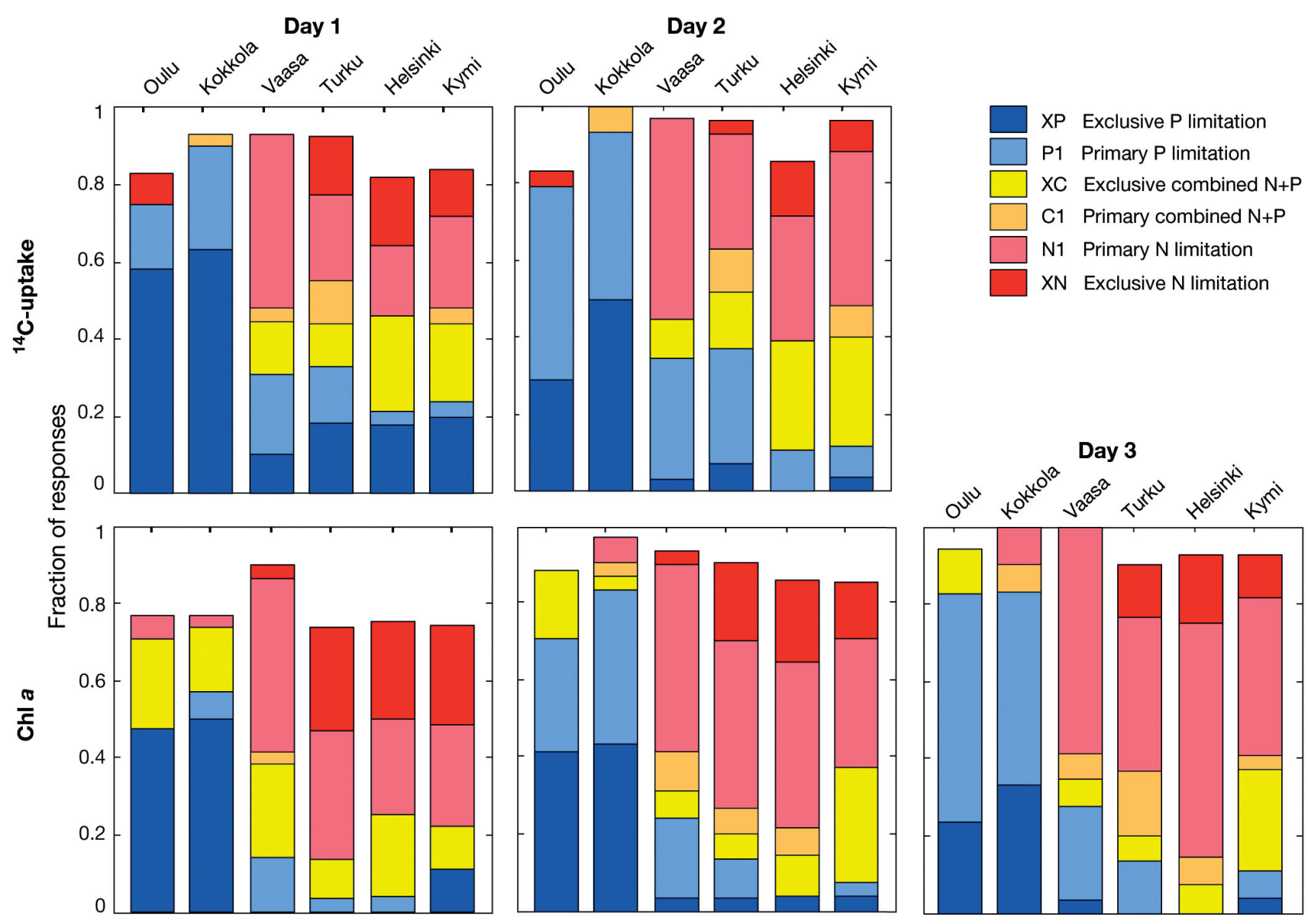

Fig. 4. Relative frequencies of limitation classes by location, response parameter, and incubation time. First row: ${ }^{14} \mathrm{C}$-uptake responses; second row: chl a responses. First column classifications are based on Day 1 responses only, second column on Days 1 and 2, and third column on all measurements on Days 1 to 3 (chl a response only). The frequency of experiments with no significant response to nutrient addition (class 00) is represented by the difference between 1 and height of bar

height of bar in Fig. 4 panels) was smaller and decreased faster with time. Exclusive P limitation (XP) of the ${ }^{14} \mathrm{C}$-response was apparent in ca. $20 \%$ of the cases on Day 1 (Fig. 4, upper left panel) even at southern locations, where chl a responses were strongly dominated by $\mathrm{N}$ limitation (Fig. 4, lower left panel). This role of $\mathrm{P}$ limitation in ${ }^{14} \mathrm{C}$-uptake responses was attenuated during Day 2 for the 4 southern stations but remained the dominant response in the north, although generally shifting from exclusive (XP) to primary $\mathrm{P}(\mathrm{P} 1)$ limitation during the course of the experiment (Fig. 4, first row panels).

$\mathrm{Chl}$ a responses initially contained a relatively large share of combined limitation responses (XC, C1), even at the northern stations, but with the exception of the easternmost Kymi station, they became marginal during the experiment (Fig. 4, second row panels). Also the relatively large share of exclusive limitation responses on Day 1 (XP at the 2 northernmost stations and XN at the others) gave way to corresponding primary limitation categories (P1, N1) during Days 2 and 3, when combined limitation responses also developed somewhat from exclusive (XC) to primary (C1) limitation. In general, chl a responses indicated a central role of $\mathrm{N}$ limitation in the southern basins, representing up to $80 \%$ of cases in Helsinki toward the end of the pooled $3 \mathrm{~d}$ experiment, while agreeing with primary productivity responses on the overwhelming P limitation $(>80 \%$ of cases) of the northernmost, Bay of Bothnia basin.

Although the responses in primary productivity and chl a varied systematically between the locations, the overall development indicated some level of temporal uncoupling between the 2 parameters. The primary productivity responses developed faster and typically resembled the chl a responses of the subsequent day. All other pair-wise comparisons between the 2 parameters were less related (Fig. 4 ; based both on the percentage of identical classifications and the contingency 
analysis likelihood ratio Chi-square test, $\mathrm{p}<0.001)$. Evidently the increased photosynthetic activity, in direct response to increased nutrient availability, manifested as a matching biomass increase with a time lag. Although increased chl a per unit biomass cannot be ruled out, it is reasonable to expect that accumulated algal growth is the major contribution to the chl a responses.

When the responses of the 2 parameters were cross-tabulated experimentwise (Table $3,{ }^{14} \mathrm{C}$ responses on Day 2 versus chl a responses on Day 3) $56 \%$ (86 out of 154) of the experiments showed an identical classification by both parameters (diagonal cells in Table 3). It is apparent that there was a consistent tendency for ${ }^{14} \mathrm{C}$ uptake responses to produce classification leaning more towards P limitation, while chl a response classifications were biased towards $\mathrm{N}$ limitation. If offsets of one category along the gradient of classifications are pooled with identical classifications, the parameters agree in $74 \%$ of the cases (114 out of 154). No-response categories $(00)$ were scarce in both parameters $(7$ or 8 cases out of 154 , or $5 \%$ ).

The most notable dissimilarity between the 2 classifications (27 out of 154 , or $18 \%$ ) represented cases where chlorophyll responses reported classifications 2 categories or more off the ${ }^{14} \mathrm{C}$ response towards $\mathrm{N}$ limitation. Chl a response classifications were biased correspondingly towards $\mathrm{P}$ limitation in only 2 cases out of 154 (Table 3). In general, the association between the 2 response parameter classifications was high (likelihood ratio $\chi^{2}=189.59, \mathrm{p}<0.001$ ). The marginal distributions, however, summarize the tendency of chl a responses to report more N-limitation cases and ${ }^{14} \mathrm{C}$ responses more leaning towards $\mathrm{P}$ limitation (Fig. 5).

\section{Seasonal patterns of the responses}

For an overview of the limitation patterns over the seasonal succession at each location, the limitation classes were pooled into P limitation (classes XP and $\mathrm{P} 1$ ), combined $\mathrm{P}$ and $\mathrm{N}$ limitation (classes $\mathrm{XC}$ and $\mathrm{C} 1$ ) and $\mathrm{N}$ limitation categories (classes $\mathrm{XN}$ and $\mathrm{N} 1$ ), expressed as bootstrap probabilities based on the relative frequencies of limitation classes after 1000 random selections among the unit-level replicates. The 3 successive experimental years are jointly displayed for ${ }^{14} \mathrm{C}$ uptake and chl a responses (Figs. 6 \& 7, respectively).
The 2 northernmost stations (Oulu and Kokkola, in the Bay of Bothnia) showed very consistent and strong $\mathrm{P}$ limitation indicated by both response parameters throughout the growth season, with only occasional combined or $\mathrm{N}$ limitation incidents around midsummer, mainly manifested in chl a responses at the Kokkola station (Fig. 7). The intermediate Bothnian Sea and Archipelago Sea stations (Vaasa, Turku), however, demonstrated a very clear seasonal development in terms of $\mathrm{P}$ and $\mathrm{N}$ limitation.

At the Bothnian Sea station (Vaasa), there was a clear-cut shift from $\mathrm{P}$ limitation in spring to $\mathrm{N}$ limitation in summer (June to August), and back to P limitation in autumn, especially according to primary productivity responses (Fig. 6). The chl a responses also clearly

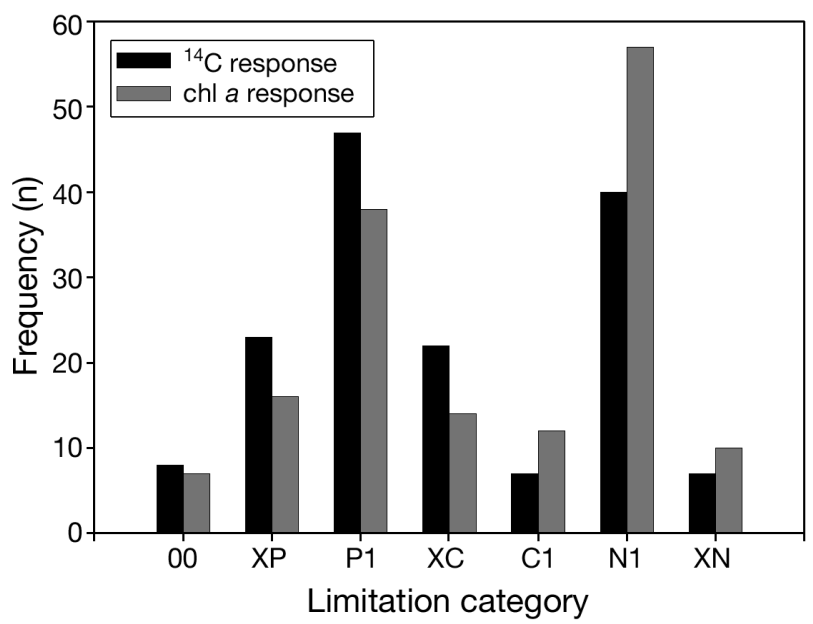

Fig. 5. Nutrient limitation classes based on ${ }^{14} \mathrm{C}$-uptake response on Day 2 versus chl a response on Day 3 (the marginal distributions of Table 3). Limitation class codes: $00=$ No response $; \mathrm{XP}=$ Exclusive $\mathrm{P}$ limitation; $\mathrm{P} 1=$ Primary $\mathrm{P}$ limitation; $\mathrm{XC}=$ Exclusive combined limitation; $\mathrm{C} 1=$ Primary combined limitation; $\mathrm{N} 1=$ Primary $\mathrm{N}$ limitation; $\mathrm{XN}=$ Exclusive $\mathrm{N}$ limitation 


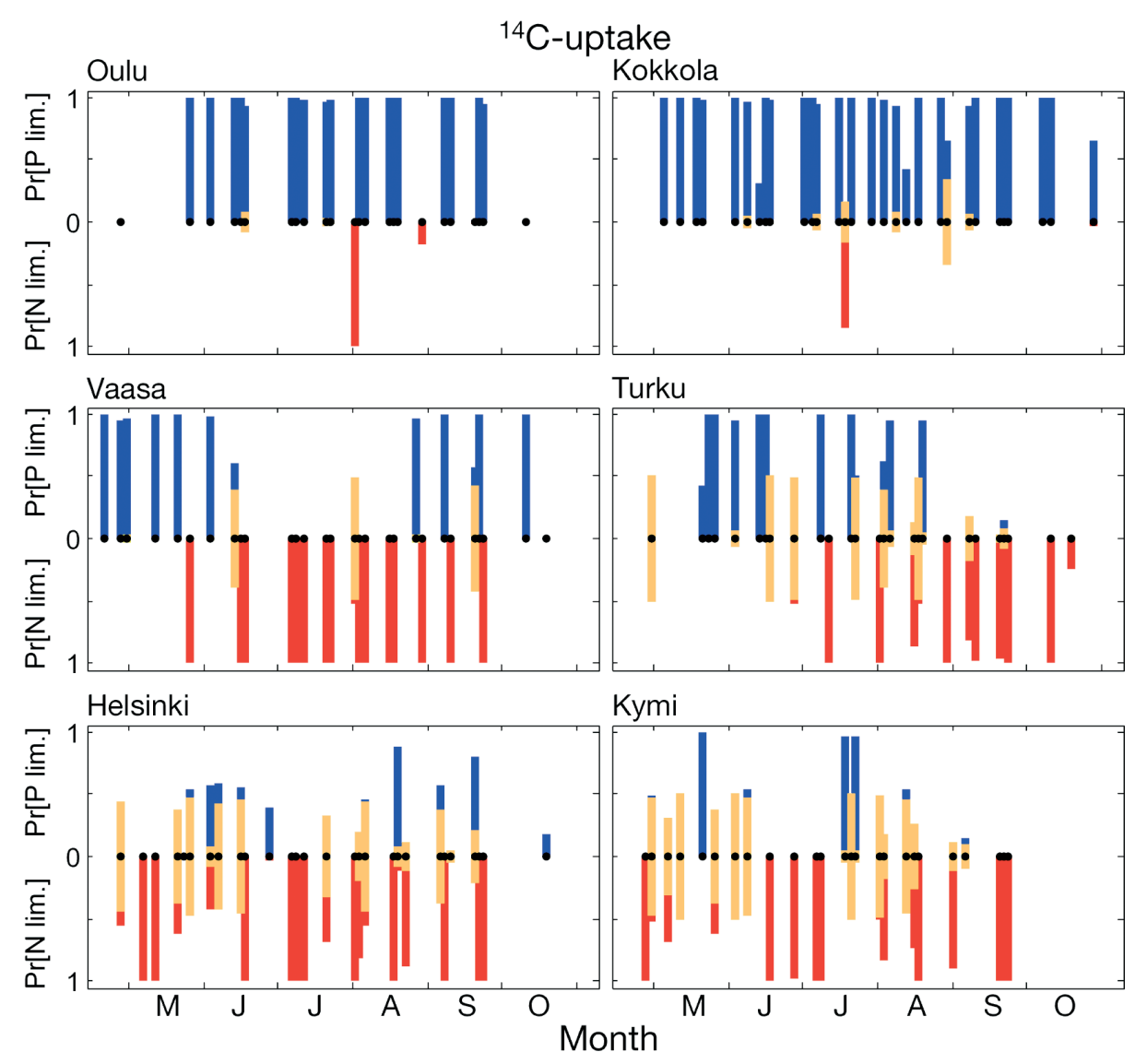

Fig. 6. Bootstrap probabilities (Pr) of $\mathrm{P}$ and $\mathrm{N}$ limitation inferred from ${ }^{14} \mathrm{C}$-uptake (Day $1-2$ responses), by location and season. Each experiment is classified 1000 times based on random selection within each duplicate measurement at the lowest replication level, and probabilities estimated by relative frequencies of different limitation classes. Accumulated probabilities for the $2 \mathrm{P}$ limitation classes (XP and P1; blue bars) shown positive upward, the $2 \mathrm{~N}$ limitation classes (XN and N1; red bars) positive downward, and the combined $\mathrm{P}$ and $\mathrm{N}$ limitation classes ( $\mathrm{XC}$ and $\mathrm{C} 1$; yellow bars) divided evenly between the two. Experiments with no significant response to nutrient addition (class 00) are marked only by black dots. Observations from the same week in different years are offset by $\pm 2 \mathrm{~d}$ to avoid overlap

showed more evidence of $\mathrm{N}$, or combined $\mathrm{N}$ and $\mathrm{P}$ limitation during the spring and autumn periods (Fig. 7), but both parameters agreed on complete $\mathrm{N}$ limitation during the summer months.

At the Archipelago Sea station (Turku), the shift from $\mathrm{P}$ limitation of primary productivity prevailing in early summer to $\mathrm{N}$ limitation occurred later in the season (late August), with $\mathrm{N}$ limitation dominating throughout the autumn (Fig. 6). Chl a responses during the spring bloom (late April, early May) were clearly N-limited (Fig. 7); unfortunately spring bloom primary productivity samples from this location were available only for one sampling over the study years (Fig. 6). The share of combined $\mathrm{N}$ and $\mathrm{P}$ limitation in both parameter responses was high at this station throughout almost the entire growth season, but especially during summer months, and the successional pattern was in general much more variable than in the northern Bothnian
Sea (Vaasa), as successive years could also produce contrasting limitation results for equal time of season during summer months.

The 2 southernmost locations (Helsinki and Kymi, Gulf of Finland) showed generally consistent $\mathrm{N}$ limitation, although periods with significant $\mathrm{P}$ responses occurred, especially reflected in primary productivity responses of the post-spring bloom season (late May and early June), and autumn (Fig. 6). The share of combined $\mathrm{N}$ and $\mathrm{P}$ limitation was relatively high for primary productivity throughout the growth season in the Gulf of Finland, but at the Helsinki station the chl a responses were unequivocally N-limited (Fig. 7). Despite the $\mathrm{N}$ limitation dominance in chl a responses at the easternmost Kymi station as well, this station showed clearly more overall heterogeneity over the seasonal cycle, resembling the Archipelago Sea station (Turku) in this respect. 


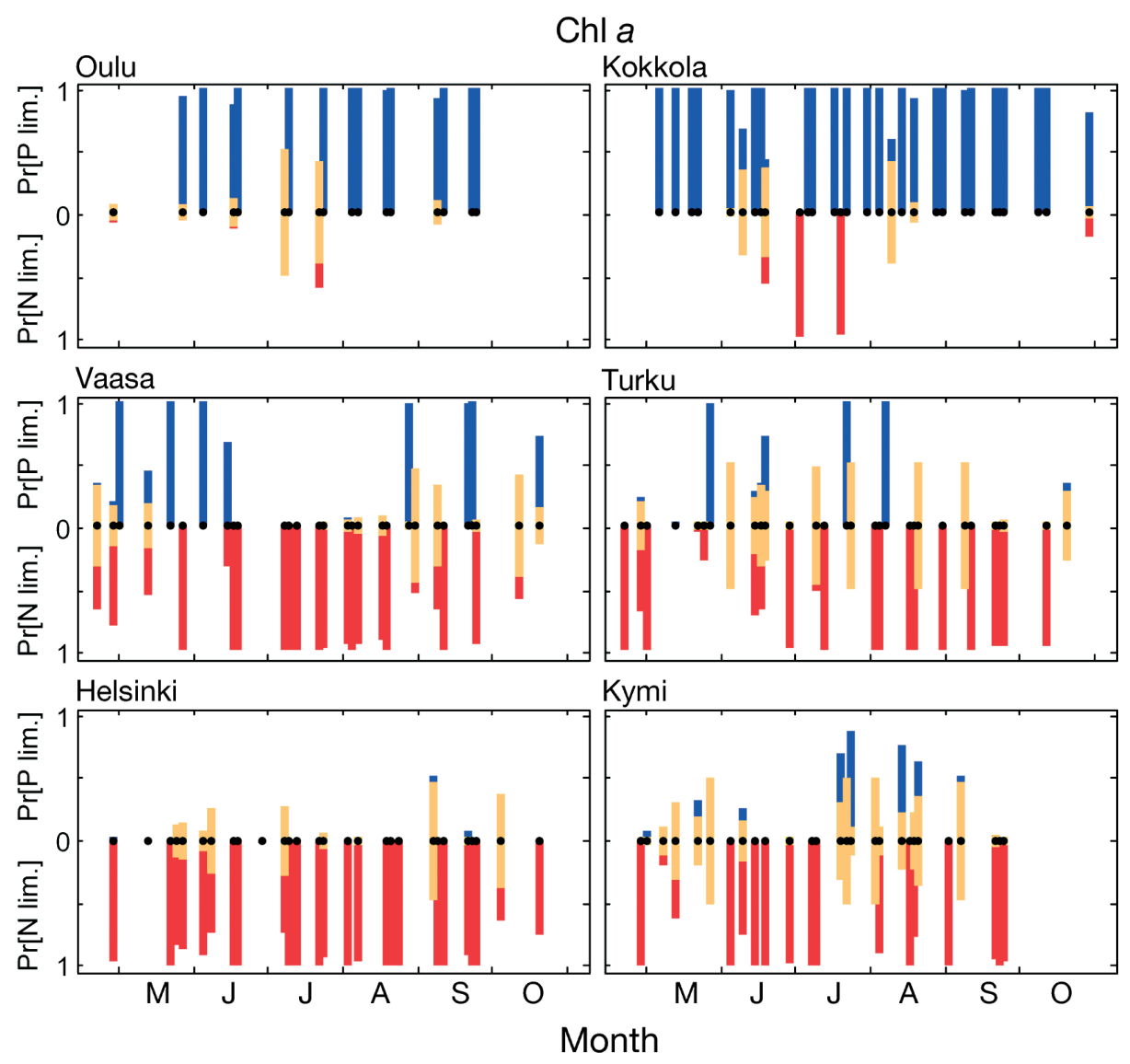

Fig. 7. Bootstrap probabilities (Pr) of P and N limitation inferred from chl a (Day 1-3 responses), by location and season. See legend to Fig. 6 for detailed explanation

\section{DISCUSSION}

\section{Bioassay responses and in situ phytoplankton limitation}

Both the loading ratios to the northern Baltic Sea (Stålnacke et al. 1999), and total N:P ratios at all stations (Table 1), suggest $\mathrm{P}$ as the dominant limiting nutrient throughout the northern Baltic Sea. The initial inorganic nutrients, however, would imply predominant $\mathrm{P}$ limitation only at the 2 northernmost stations (situated in the Bay of Bothnia), while in the remaining areas the low DIN and DIP levels provide a very uncertain basis for limitation assessment, and no seasonal succession is evident (Fig. 3). In contrast, experimental assessment of in situ limitation produced consistent patterns of limitation both between the areas, and over the growth season during the 3 yr study period (Figs. 4, 6 \& 7). It thus appears that active experimentation, with short-term responses, is able to reveal reproducible in situ limitation patterns in situations, where more static or hierarchically distant ecosystem properties appear indecisive.
The consistent tendency of primary productivity to be more P-limited and chl a increase more $\mathrm{N}$-limited (Figs. 4 \& 5, Table 3) evidently relates relate to the different roles of $\mathrm{P}$ and $\mathrm{N}$ in phytoplankton cellular metabolism. $\mathrm{P}$ is mainly required for basic cellular regulatory and energy needs (nucleic acids of which ribosomal RNA constitutes the major pool, but also free nucleotides and phospholipids), while $\mathrm{N}$ is mainly used in proteins but is also needed for nucleic acids and key components of the photosynthetic machinery such as chlorophyll (Falkowski 2000, Geider \& La Roche 2002, and references therein). The unequal association of $\mathrm{P}$ and $\mathrm{N}$ limitation patterns with the response parameters makes general sense if we assume that relatively more $\mathrm{P}$ is needed for the cellular energy and regulatory processes more closely related to the ${ }^{14} \mathrm{C}$ uptake response, while more $\mathrm{N}$ is needed for the biomass increase estimated by the chl a response.

The temporal development of responses in primary productivity and chl a during the 3 experimental days was gradual but distinct (Fig. 4). The share of indistinguishable responses became marginal in ${ }^{14} \mathrm{C}$ uptake after Day 1, while it took one day more for chl a 
responses. Statistically, all dates for both parameters showed high resemblance ( $p<0.001$ for all pairwise likelihood ratio Chi-square tests), but a response succession pattern was evident for both parameters. Successive days produced identical chl a limitation classes in $52 \%$ (Day 1 to Day 2) and 68\% (Day 2 to Day 3) of the experiments, but only $35 \%$ of chl a response classifications were identical on Days 1 and 3. This gradual development was mainly due to the exclusive limitation classes $(\mathrm{N}, \mathrm{P}$, and combined) diluting to corresponding primary limitation classes.

The exclusive limitation categories as defined here (see 'Materials and methods' and Andersen et al. 2006) are very strict in the sense that for the single limitation cases (XN or XP), any departure of the non-limiting nutrient from control, or the limiting nutrient from the combined $(\mathrm{P}+\mathrm{N})$ treatment, will shift the classification into one of the other limitation classes. The generally observed difference between the exclusive and primary single nutrient limitation classes in the data was that the single limiting nutrient treatment started to lag behind the combined nutrient addition at some phase of the experiment, i.e. the effect of the non-limiting nutrient was only visible through its effect in combination with the limiting one (see 'Materials and methods'). The exclusive limitation outcomes thus describe planktonic communities with abundant supply of the non-limiting nutrient over the whole duration of the experiment. The interpretation on both the cellular and community metabolism level is straightforward: only one nutrient is lacking.

The dominant XP limitation in the northernmost Bay of Bothnia basin (Fig. 4, stations Oulu and Kokkola) represents the most clear-cut example of a 'pure and simple' limitation pattern. However, even at these stations, only ca. $60 \%$ of the responses produced the exclusive P (XP) limitation class in Day $1{ }^{14} \mathrm{C}$-uptake responses, while almost $50 \%$ of all experiments were classified as primary P limitation (P1) on Day 2 (Fig. 4). A similar replacement of XN by $\mathrm{N} 1$ classes was even more pronounced in chl a responses from Day 1 to 3 . At the predominantly $\mathrm{N}$-limited southern sites, the share of primary N limitation (N1) was higher to start with, and the dominance of this class increased among chl a responses during the successive days (Fig. 4).

It appears that planktonic communities growing under relative abundance of the non-limiting nutrient have adapted their metabolism by stocking their intracellular reserves with the non-limiting nutrient. The initial boosting of production and consequent biomass synthesis may thus be based on utilization of the experimentally increased supply of the limiting nutrient alone for a limited period of time, corresponding to a few cell divisions ( 1 to $2 \mathrm{~d}$, Fig. 4). After this, exclusive limitation is replaced by primary limitation by the same nutrient, as the initially non-limiting one is exhausted from cellular reserves.
When the responses are used to interpret nutrient limitation prevailing in the initial community, the exclusive and primary limitation categories would thus seem to be successive temporal stages of a main limitation pattern, and for most applied purposes the limitation classes could be pooled into 3 basic categories: $\mathrm{P}$, $\mathrm{N}$ and combined limitation $(\mathrm{XP}+\mathrm{P} 1, \mathrm{XN}+\mathrm{N} 1, \mathrm{XC}+\mathrm{C} 1)$.

Although the response patterns of ${ }^{14} \mathrm{C}$ uptake and chl a suggested different roles of $\mathrm{P}$ and $\mathrm{N}$ in phytoplankton limitation, both responses were overall significantly alike. The degree of uncoupling of primary production and biomass synthesis appears thus to be minor and mainly temporal. Such decoupling would imply an adaptively valuable buffering plasticity of phytoplankton metabolism with respect to the fluctuating resource availability of the planktonic habitat.

\section{Food web modifications and experimental artifacts in responses}

The goal of running bioassays is to produce information on the planktonic assemblage at the time of sampling. The inherent problem of any bioassay setup is therefore a tradeoff between 2 concerns. On one hand, the duration of the experiment should be sufficient to produce reliably measurable, as well as unambiguously interpretable responses to nutrient manipulations. On the other hand, accumulating experimental artifacts ('bottle effects') will also increase with time, possibly confounding the extrapolation of observed responses back to the initial situation.

These artifacts could arise from several sources. The confined experimental conditions can select for or against different algal or grazer species present in the natural community; the prevailing balance between nutrient assimilation and regeneration within the planktonic food web can be disrupted by the exclusion or uneven distribution of larger and less abundant components of the food web; and the potentially important spatial flows of nutrients affecting their in situ availability in the euphotic layer of the natural system (like sedimentation and advection) are cut off completely.

Phytoplankton community succession is a potentially confounding effect in bioassays (e.g. Pollingher et al. 1988), but constraining the length of the assay should safeguard against excessive community changes. Mimicking the natural conditions in terms of temperature and light quality is obviously important for minimizing artificial effects in assays. In order to attain reliable limitation patterns for nutrients, light levels should match saturating conditions and not impose additional limiting factors in the setup, invalidating the analysis (Andersen et al. 2006). 
Perhaps the most difficult experimental artifact to avoid is the confinement effect creating an artificial turbulence regime. In our experiments, no attempt was made to mimic natural turbulence conditions, so it is possible that non-motile species were not performing naturally in spite of mixing the experimental bottles twice daily, and sinking out of saturating light conditions is not possible in confinement. In the absence of microscopy data, no estimate of this type of artificial succession is available. However, the regular mixing of experimental bottles during the shortterm experiments should also rule out excessive $\mathrm{pH}$ changes and related $\mathrm{CO}_{2}$ shortage, which according to our culture experience takes place at phytoplankton cell densities far above the natural community levels encountered in the experiments (for initial chl a levels, see Fig. 3).

The time series approach of our assays allowed us to distinguish between linear and higher-order (quadratic, cubic) time effects of the treatments (see Andersen et al. 2006), of which the latter were the most common in the data (percentages of linear, quadratic and cubic time effects in chl a responses were $14 \%, 32 \%$ and $55 \%$, respectively), and they typically reflected the transition from exclusive to primary limitation of a single nutrient. Significant 3rd-order time effects were often accompanied by decreasing phytoplankton biomass at the end of the experiment, very probably reflecting a delayed response of grazers to increased prey abundance. As the natural planktonic communities were not subject to any pre-screening treatment, the microbial food web was present at natural abundances, including crustacean zooplankton.

It is obvious that over the seasonal succession, smaller grazers (rotifers, ciliates, nanoflagellates) will also be important components of the food web in the Baltic Sea as elsewhere (Kivi 1986, Kuosa \& Kivi 1989), with ciliate and nanoflagellate growth rates matching those of their algal prey (Kuuppo-Leinikki et al. 1994). Tight grazing control would dampen down the phytoplankton biomass responses to nutrient enrichment. Kivi et al. (1993) demonstrated type of cascading enrichment effect with a comparable experimental setup, as ciliate biomass showed clear responses to nutrient additions in the time scale of corresponding but minor phytoplankton responses.

An interesting indication of non-intuitive food web effects was a response pattern that was reproduced several times (ca. $5 \%$ of the experiments) over the experimental campaign, and which appears at first sight nonsensical: the combined $\mathrm{N}+\mathrm{P}$ addition produced a strong chl a response accompanied by a weaker but distinct $\mathrm{N}$ response, as well as by a significant negative $\mathrm{P}$ response (see examples in Andersen et al. 2006). The classification method reports the out- come as primary combined limitation (C1), as it does not take into account the signs of responses.

This might seem a handicap of the classification scheme, as combined limitation categories with positive responses are easily conceived as describing a phytoplankton community with compartments limited by different nutrients, but inhibition by moderate $\mathrm{P}$ addition is not really explainable. However, bacterioplankton are naturally present in the bioassays, and if they have access to an organic $\mathrm{N}$ source unavailable to N-limited phytoplankton, their competition for $\mathrm{P}$ can lead to decrease in algal biomass, as demonstrated by Thingstad et al. (2005). Although both algae and bacteria have been shown to utilize organic $\mathrm{N}$ and $\mathrm{P}$, this is more widespread in heterotrophic nutrition (e.g. Berman \& Bronk 2003). All below-control responses in our experiments were for single $\mathrm{P}$ treatment, never for single $N$, suggesting more intense competition between algae and bacteria for DIP than for DIN.

In summary, time series based bioassays with appropriate setup and analysis of the responses can yield important insights on the in situ limitation, as well as on the production dynamics and functioning of the planktonic food web. This includes both basic phytoplankton responses, and their interactions with other food web compartments. However, reliable interpretation of different types of cascading food web effects, though indicated by phytoplankton responses, would naturally require additional information on the main heterotrophic organism groups.

\section{Seasonality in nutrient limitation patterns}

The high frequency of combined or non-exclusive limitation outcomes at all locations indicates close couplings between $\mathrm{P}$ and $\mathrm{N}$ cycles in the planktonic ecosystem. This is further emphasized by the seasonal patterns of nutrient limitation (Figs. 6 \& 7). Even in the cases of relatively clear-cut P limitation in the Bay of Bothnia and $\mathrm{N}$ limitation of the Gulf of Finland, the severity of the dominant limitation pattern changes during the season. The post-spring bloom and/or summer period showed instances of combined limitation, or even occasional limitation by the non-predominant nutrient. The Bothnian Sea station (Vaasa) showed a very consistent pattern of seasonal development of the limiting nutrient, as spring and autumn were clearly Plimited, but summertime showed unequivocal $\mathrm{N}$ limitation during all study years (Figs. 6 \& 7). Seasonality in limitation patterns was apparent at the Archipelago Sea (Turku) and Gulf of Finland (Helsinki, Kymi) stations as well, although variability during all seasons was clearly higher in the southern basins, especially at the Turku and Kymi stations. 
Seasonality in nutrient limitation of the planktonic community has been previously observed in several environments, mainly in lakes (Pollingher et al. 1988, Vanni \& Temte 1990, Elser et al. 1990, Sterner 1994) but also in a variety of coastal environments (D'Elia et al. 1986, Paasche \& Erga 1988, Fisher et al. 1999). Our results demonstrate that the seasonal patterns can be highly reproducible, and they can vary distinctly even between closely related environments (as in the northern basins Bay of Bothnia and Bothnian Sea; Figs. 6 \& 7).

In systems exhibiting seasonal patterns in nutrient limitation, an analysis of the basin-wide biogeochemical cycles behind the limitation patterns is obviously a major challenge for targeting eutrophication control actions effectively. Basic load-response models without explicit seasonal dynamics appear insufficient for these environments. Understanding the causes of seasonal limitation shifts requires combining experimental limitation assessment and monitoring data in order to analyze the biogeochemical nutrient cycles, and especially their interactions.

Hydrographically mediated, seasonal vertical nutrient fluxes between the surface and bottom layers are potentially important features of environments where seasonal patterns in nutrient limitation are encountered. Mechanisms for these shifts could include selective (non-Redfield) removal of nutrients from the euphotic zone via sedimentation (Heiskanen et al. 1996, Thomas et al. 1999), unbalanced losses of $\mathrm{N}$ and $\mathrm{P}$ at the sediment-water interface via denitrification and, according to oxygen conditions, iron precipitation or release of $\mathrm{PO}_{4}$ (Seitzinger 1988, Blomqvist et al. 2004). Seasonal and episodic mixing events introduce the modified (in terms of N:P) near-bottom waters back to the productive layers. Seasonal limitation shifts would thus appear most likely in relatively shallow temperate waters.

\section{Cyanobacteria and N-limitation}

In the case of the Baltic Sea, the picture is further complicated by the occurrence of $\mathrm{N}_{2}$-fixing filamentous cyanobacterial blooms, common in lakes but generally absent from oceanic coastal regions. These blooms (with dominant species Nodularia spumigena and Aphanizomenon sp.) have regularly occurred in the southern basins including the Baltic Proper, but not in the Gulf of Bothnia (Kahru et al. 1994, Larsson et al. 2001). Sedimentary evidence suggests that they have been a component of the Baltic Sea ecosystem throughout its present brackish state (Bianchi et al. 2000). Cyanobacterial blooms should primarily be nutritionally dependent on dissolved $\mathrm{P}$ due to their access to atmospheric $\mathrm{N}_{2}$.
The southern basins around Finland (Archipelago Sea, Gulf of Finland) were predominantly N-limited throughout the whole growth season, as was the Bothnian Sea for the summer months (station Vaasa, Figs. 6 \& 7). Yet cyanobacterial blooms appear for limited summertime periods, and in the southern basins only (Kahru et al. 1994). It is therefore evident that causes for the cyanobacterial blooms in the Baltic Sea are more complicated than just a matter of $P$ surplus and sufficiently high temperature, which has so far been the standard interpretation (see Larsson et al. 2001). Recent evidence on the variability in species-specific responses of filamentous and colonial cyanobacteria to $\mathrm{N}$ and $\mathrm{P}$ enrichment supports this conclusion (Kangro et al. 2007).

The spring bloom is by far the most productive period of the growth season in the northern Baltic Sea (Lignell et al. 1993), supplying the largest sedimentation flux to bottoms (Heiskanen 1998). This season is unequivocally N-limited in the areas where cyanobacterial blooms occur (Figs. 4, 6 \& 7). Monitoring data since the experimental period of this study suggest that $\mathrm{N}$ limitation of the spring bloom has even intensified, as inorganic $P$ levels remaining after the bloom period have clearly increased in the Gulf of Finland since mid-1990s (Finnish Environment Institute unpubl. data).

The interactions and feedbacks between $\mathrm{N}$ and $\mathrm{P}$ cycles appear clearly on the system level in the Baltic Sea. The consequence of increasing $\mathrm{N}$ availability at the commencement of the N-limited spring bloom is higher biomass production and sedimentation, leading to enhanced $\mathrm{P}$ release from sediments in summer due to enhanced oxygen consumption. Aggravated $\mathrm{P}$ release from the sediments has indeed been recently demonstrated in the Gulf of Finland, in connection to increased anoxic coastal bottom areas over the permanent halocline (Pitkänen et al. 2001).

High springtime $\mathrm{N}$ levels would therefore tend to maintain high summertime $\mathrm{P}$ levels, favoring the cyanobacterial blooms, importing more $\mathrm{N}$ to the system - a vicious eutrophication circle which is obviously impossible to tone down without significantly decreasing both the $\mathrm{N}$ and $\mathrm{P}$ loads to the system. Nitrogen fixation does not appear to compensate for the recently escalated relative shortage of $\mathrm{N}$ on the system level, as the increasing $P$ levels in the southern basins have not been followed by Redfield-proportional $\mathrm{N}$ increases over a decade - to the contrary, $\mathrm{N}$ concentrations have shown a simultaneous decrease (Finnish Environment Institute, Swedish Meteorological and Hydrological Institute unpubl. data). This indicates that on time scales relevant for management perspectives, decreased $\mathrm{N}$ loads to dampen down the spring bloom production would very unlikely be quantitatively compensated by enhanced $\mathrm{N}_{2}$-fixation. 


\section{The northern Baltic Sea basins: lakes or coastal zones?}

Our results confirm and extend previous evidence of prevailing $\mathrm{N}$ limitation of the southern Baltic Sea basins (Gráneli et al. 1990, Elmgren \& Larsson 1997), Gulf of Finland (Kivi et al. 1993, Pitkänen \& Tamminen 1995) and Gulf of Riga (Seppälä et al. 1999). The only predominantly P-limited coastal areas (Figs. 4, 6 \& 7) were situated in the Bay of Bothnia (Fig. 1; Oulu, Kokkola), where average salinities were below 3.5 PSU (Table 1). The transition between $\mathrm{P}$ and $\mathrm{N}$ limitation patterns occurs over a surprisingly narrow salinity range. The eastern Gulf of Finland (Kymi), with an average salinity of 3.6 PSU, showed predominant N limitation, and the northern part of Bothnian Sea (Vaasa), which is situated only some $150 \mathrm{~km}$ south of the P-limited Kokkola station, was clearly N-limited throughout the summer months.

The persistent difference in the average salinities of the stations of the 2 northernmost basins (Bay of Bothnia and Bothnian Sea; $<3.5$ and 5.1 PSU, respectively; Table 1) is a reflection of the anti-clockwise circulation patterns of the basins, which force the voluminous freshwater inflow into the Bay of Bothnia (from northern Finnish and Swedish rivers) southward along the western, Swedish coastline. The eastern, Finnish side of the Bothnian Sea thus receives more saline waters originating from the south, Archipelago Sea and Baltic Proper (Mälkki \& Tamsalu 1985). It is therefore possible that the P-limited regime extends further south to the northern Bothnian Sea on the western, Swedish coast. However, the Quark strait that divides the Gulf of Bothnia into 2 major basins (Bay of Bothnia and Bothnian Sea) seems to be a geographical threshold for transition from predominant $\mathrm{P}$ to $\mathrm{N}$ limitation.

Besides the salinity regimes, the study areas differ significantly in the degree of anthropogenic eutrophication as reflected in the average total nutrient and chl a concentrations (Table 1, Fig. 3). The 2 Gulf of Finland stations (Helsinki and Kymi) stand out in terms of eutrophication, with the Archipelago Sea in an intermediate position. These large-scale differences are due to intensive agriculture and large municipal and industrial point sources around the southern basins. The Gulf of Finland catchment area includes the largest river discharging into the Baltic Sea (the Neva) flowing through the largest coastal city, St. Petersburg, located at the easternmost end of the Gulf. In contrast, the Gulf of Bothnia catchment is very sparsely populated with modest point sources of nutrients and land use dominated by forestry (Stålnacke et al. 1999, HELCOM 2004).

Increasing eutrophication appears to shift the P limitation of Baltic pristine low-saline areas towards N lim- itation, as demonstrated by the contrast between Kokkola and Kymi stations with closely corresponding salinities. The persistent $\mathrm{N}$ limitation of the eutrophic Helsinki station differs clearly from the seasonally shifting $\mathrm{P}$ and $\mathrm{N}$ limitation of the Vaasa station, although their average salinities are similar (Table 1, Figs. 4, $6 \&$ 7). Previous studies from the most eutrophied eastern Gulf of Finland (Pitkänen \& Tamminen 1995) and the eutrophic Gulf of Riga (Seppälä et al. 1999) have demonstrated that $N$ limitation occurs in these environments at salinities comparable to the P-limited Bay of Bothnia.

The mechanisms for the tendency of eutrophication to drive the system towards $\mathrm{N}$ limitation are most likely connected to intensified pelagic-benthic coupling in the eutrophied Baltic areas. This causes less permanent removal of $\mathrm{P}$ through sedimentation, as well as increasing removal of $\mathrm{N}$ through denitrification, under conditions of reduced oxygen levels in bottom layers. Despite high N:P ratios prevailing in terrestrial loading (for the Baltic Sea as a whole, triple the Redfield ratio; Stålnacke et al. 1999, HELCOM 2004), the surface layer inorganic N:P ratio tends to decrease rapidly, even clearly below the Redfield ratio, under eutrophic conditions (Pitkänen \& Tamminen 1995, Tamminen \& Seppälä 1999), a phenomenon observed also in other coastal systems (Fisher et al. 1999).

The highest variability in nutrient limitation patterns both seasonally (Figs. $6 \&$ \%) and in general (Fig. 4) was found at the Turku (Archipelago Sea) and Kymi (eastern Gulf of Finland) stations. The most likely explanation for this heterogeneity is their closest proximity to the anthropogenic point sources of nutrients. Local fish farming constitutes a large fraction of the nutrient load within the mosaic of the Archipelago Sea (Hänninen et al. 2000), whereas the largest nutrient load to the Gulf of Finland is discharged into the easternmost estuary from the Neva river and city of St. Petersburg (HELCOM 2004, Kuuppo et al. 2006), only $\sim 150 \mathrm{~km}$ from the Kymi station. Continuous nutrient discharges, conveyed by weather-driven variable surface currents, obviously diversify the annual development of limitation patterns in these areas.

Our results indicate that nutrient limitation patterns in coastal low-salinity regimes are modified towards $\mathrm{N}$ limitation when exposed to eutrophication pressure. Prediction of nutrient limitation on the basis of salinity or loading ratios is not reliable. The high fraction of non-exclusive limitation categories in our experiments demonstrates that phytoplankton can grow close to balanced limitation for extended periods of the season, which creates considerable methodological challenges for limitation assessment, and necessitates dedicated experimentation. 


\section{P vs. $\mathbf{N}$ limitation}

The demonstration of closely coupled $\mathrm{P}$ and $\mathrm{N}$ cycles and their seasonal interplay in nutrient limitation of the coastal Baltic Sea carries obvious implications for environmental management in the catchment area, but also points out some important aspects of the role of coastal zones in general. The dynamic processes transforming the terrestrial nutrient loading within the coastal system make nutrient limitation patterns inferred from loading ratios very uncertain. Seasonality in nutrient limitation has been demonstrated in widely differing coastal areas like the Baltic Sea (Kivi et al. 1993, this study), the Gulf of Mexico (Lohrenz et al. 1999), the Oslo fjord (Paasche \& Erga 1988), and Chesapeake Bay (D'Elia et al. 1986, Fisher et al. 1999). Seasonality further underlines the significance of coastal biogeochemical cycles in modifying the terrestrial nutrient signals at a distance within the range of human vision from coastal point sources.

A potentially interesting corollary of the dynamic role of the coastal zone relates to the discussions on the nutrient limitation of the World Ocean. Redfield's original concept of self-regulating oceans via planktonic stoichiometry (Redfield 1934, 1958) was recently formulated into a 1-dimensional model (Tyrrell 1999) built on 2 basic assumptions: terrestrial nutrient fluxes are evenly distributed over the World Ocean, and temporary $\mathrm{N}$-limited phases are relieved by $\mathrm{N}_{2}$-fixation. From these assumptions it appears that an 'ultimate $\mathrm{P}$ limitation' cannot be avoided.

In the northern Baltic Sea we could verify neither of these assumptions. The nutrient loading does not reach offshore areas without major modifications and losses, as N-rich terrestrial nutrient exports are transformed in near-coast environments into N-limited pelagic domains. The verified $\mathrm{N}$ limitation does not automatically lead to appearance of $\mathrm{N}_{2}$-fixing plankton blooms (Bothnian Sea), and even in areas where the whole growth season is predominantly N-limited (Archipelago Sea, Gulf of Finland), the $\mathrm{N}^{2}$-fixing blooms appear only for a fraction of the season. The main cyanobacterial blooms appear in the most offshore areas of the Baltic Proper (Kahru et al. 1994), with maximal distance from terrestrial nutrient sources-not unlike the global distribution of the major diazotroph Trichodesmium (Capone et al. 1997). As the seasonal cycle in the southern Baltic Sea basins recurrently starts from a strongly $\mathrm{N}$-limited spring bloom, it appears that $\mathrm{N}_{2}$-fixation during late summer cannot alleviate the basic N-limitation pattern on the basin scale.

If this geographical and temporal uncoupling of terrestrial nutrient loads and offshore $\mathrm{N}_{2}$-fixation appears in the relatively small scale of the Baltic Sea, where the nitrogen-fixing planktonic species portray globally exceptional visibility, it is not immediately apparent how the 1-dimensional concept of the homeostatic World Ocean (Tyrrell 1999) could describe such a vast system realistically. It is obvious that the complexity of the nutrient cycles within marine microbial communities, including coastal zone dynamics as well as nonRedfield behavior and multiple resource co-limitations (Arrigo 2005), still remains a domain of aquatic sciences where immediate management interests (Cloern 2001) overlap with challenges for basic plankton physiology, stoichiometric system analyses, and understanding of biogeochemical cycles from local to global scales.

\section{CONCLUSIONS}

Nutrient limitation of natural phytoplankton communities cannot be reliably inferred from large-scale nutrient budgets, pool sizes, or loading ratios, in cases where several potential limiting nutrients show apparently low availability, or where these ecosystem qualities produce apparently contrasting conclusions. The Baltic Sea is an example where coastal processes strongly modify the nutrient loading signals, to the effect that widespread $\mathrm{N}_{2}$-fixing cyanobacterial blooms occur despite high excess of $\mathrm{N}$ in nutrient inputs to the system. We have demonstrated that active experimentation, comprising of short-term time series bioassays, coupled to a novel model selection procedure for unsupervised classification of responses, is able to reveal reproducible in situ nutrient limitation patterns that cannot be inferred from nutrient data alone. We advocate the use of a priori classification of bioassay limitation responses instead of site-specific protocols, to facilitate meaningful comparative studies of different aquatic systems.

Our limitation patterns highlighted the seasonal and vertical interplay of the cycles of $\mathrm{N}, \mathrm{P}$, and $\mathrm{O}$ in the coastal Baltic Sea, and the results help to explain the apparent discrepancy between nutrient loading and planktonic responses. The management conclusion is to delimit both $\mathrm{N}$ and $\mathrm{P}$ loading to alleviate eutrophication symptoms, because of both direct and cascading biogeochemical effects within the system. It is evident that a combination of experimental assessment of in situ limitation, monitoring data on the biogeochemical cycles of main nutrients, and seasonal hydrographical forcing of the system, is able to provide insights into the coastal modification of nutrient pools that are important both for coastal management, and for assessing the role of the coastal zone in largescale nutrient and production dynamics of the marine environment. 
Acknowledgments. This work was financed through the research contract 'Nitrogen discharge, pelagic nutrient cycles, and eutrophication of the Northern Baltic coastal environment - PELAG III' jointly funded by the Finnish Ministry of the Environment, National Board of Waters and the Environment (Finland) (now SYKE), Academy of Finland, University of Helsinki, Maj and Tor Nessling Foundation, and 25 other parties of Finnish coastal industries and towns, in 1991-1995. We are greatly indebted to the laboratory personnel of the 6 regional Water and Environment Districts (at the time), who carried out the experiments with high dedication and professional pride. We especially thank the laboratory staff in charge of the practical execution of the experiments over the years in each laboratory, namely A. Rahikainen (Oulu), T. Saari and L. Jälkö (Kokkola), K. Aulin and E. Kiviniemi (Vaasa), I. Halttunen, M. Aalto, P. Sorvali and H. Rekola (Turku), I. Virolainen, S. Parkman, M. Lehtinen and S. Virtanen (Helsinki), and L. Kurkela and M.-L. Taiminen (Kymi). The chemical and isotope analyses presented in this study were run by Elina Salminen, Mervi Sjöblom and Ulla Sjölund at the laboratory of the Tvärminne Zoological Station of the University of Helsinki, with their unrivalled precision, commitment, and spirits. The whole PELAG III research team is gratefully acknowledged for the great times. Different aspects of the in-depth data analysis have been funded by the EU 5th Framework Project DANLIM (EVK3-CT-2001-00049) and the 6th Framework Project THRESHOLDS (GLOBAL/IP/ 02/0257)

\section{LITERATURE CITED}

Andersen T, Saloranta T, Tamminen T (2007) A statistical procedure for unsupervised classification of nutrient limitation bioassay experiments with natural phytoplankton communities. Limnol Oceanogr Methods 5:111-118

Arrigo KR (2005) Marine microorganisms and global nutrient cycles. Nature 437:349-355

Beardall J, Young E, Roberts S (2001) Approaches for determining phytoplankton nutrient limitation. Aquat Sci 63: 44-69

Berman T, Bronk D (2003) Dissolved organic nitrogen: a dynamic participant in aquatic systems. Aquat Microb Ecol 31:279-305

Bianchi TS, Engelhaupt E, Westman P, Andrén T, Rolff C, Elmgren R (2000) Cyanobacterial blooms in the Baltic Sea: Natural or human-induced? Limnol Oceanogr 45: 716-726

Blomqvist S, Gunnars A, Elmgren R (2004) Why the limiting nutrient differs between temperate coastal seas and freshwaters: a matter of salt. Limnol Oceanogr 49:2236-2241

Capone DG, Zehr JP, Paerl HW, Bergman B, Carpenter E (1997) Trichodesmium, a globally significant marine cyanobacterium. Science 276:1221-1229

Caraco N, Cole J, Likens GE (1989) Evidence for a sulfatecontrolled phosphorus release from sediments of aquatic systems. Nature 341:316-318

Caraco N, Cole J, Likens GE (1990) A comparison of phosphorus immobilization in sediments of freshwater and coastal marine systems. Biogeochemistry 9:277-290

Cloern JE (2001) Our evolving conceptual model of the coastal eutrophication problem. Mar Ecol Prog Ser 210: 223-253

D'Elia CF, Sanders JG, Boynton WR (1986) Nutrient enrichment studies in a coastal plain estuary: phytoplankton growth in large-scale continuous cultures. Can J Fish Aquat Sci 43:397-406
Elmgren R, Larsson U (eds) (1997) Himmerfjärden. Rapport 4565, Naturvårdsverket Förlag, Stockholm (in Swedish, with English summary and figure legends)

Elser JJ, Marzolf ER, Goldman CR (1990) Phosphorus and nitrogen limitation of phytoplankton growth in the freshwaters of North America: a review and critique of experimental enrichments. Can J Fish Aquat Sci 47:1468-1477

Falkowski PG (2000) Rationalizing elemental ratios in unicellular algae. J Phycol 36:3-6

Fisher TR, Peele ER, Ammerman JW, Harding LW Jr (1992) Nutrient limitation of phytoplankton in Chesapeake Bay. Mar Ecol Prog Ser 82:51-63

Fisher TR, Gustafson AB, Sellner K, Lacouture R and 6 others (1999) Spatial and temporal variation of resource limitation in Chesapeake Bay. Mar Biol 133:763-778

Geider RJ, La Roche J (2002) Redfield revisited: variability of $\mathrm{C}: \mathrm{N}: \mathrm{P}$ in marine microalgae and its biochemical basis. Eur J Phycol 37:1-17

Granéli E, Wallström K, Larsson U, Granéli W, Elmgren R (1990) Nutrient limitation of primary production in the Baltic Sea area. Ambio 19:142-151

Harrison JA, Seitzinger SP, Bourman AF, Caraco NF, Beusen AHW, Vörösmarty CJ (2005) Dissolved inorganic phosphorus export to the coastal zone: results from a spatially explicit, global model. Global Biogeochem Cycles 19 doi:10.1029/2004GB002357

Hecky RE, Kilham P (1988) Nutrient limitation of phytoplankton in freshwater and marine environments: a review of recent evidence on the effects of enrichment. Limnol Oceanogr 33:796-822

Heiskanen AS (1998) Factors governing sedimentation and pelagic nutrient cycles in the northern Baltic Sea. Monogr Boreal Env Res 8:1-80

Heiskanen AS, Tamminen T, Gundersen K (1996) Impact of planktonic food web structure on nutrient retention and loss from a late summer pelagic system in the coastal northern Baltic Sea. Mar Ecol Prog Ser 145:195-208

HELCOM (2002) Environment of the Baltic Sea area 1994-1998. Balt Sea Environ Proc 82B:1-215

HELCOM (2004) The 4th Baltic Sea pollution load compilation (PLC-4). Balt Sea Environ Proc 93:1-188

Howarth RW (1988) Nutrient limitation of net primary production in marine ecosystems. Ann Rev Ecol Syst 19:89-110

Hänninen J, Vuorinen I, Helminen H, Kirkkala T, Lehtilä K (2000) Trends and gradients in nutrient concentrations and loading in the Archipelago Sea, northern Baltic, in 1970-1997. Estuar Coast Shelf Sci 50:153-171

Kahru M, Horstmann U, Rud O (1994) Satellite detection of increased cyanobacteria blooms in the Baltic Sea: natural fluctuation or ecosystem change? Ambio 23:469-472

Kangro K, Olli K, Tamminen T, Lignell R (2007) Speciesspecific responses of a cyanobacteria-dominated phytoplankton community to artificial nutrient limitation: a Baltic Sea coastal mesocosm study. Mar Ecol Prog Ser 336:15-27

Kivi K (1986) Annual succession of pelagic protozoans and rotifers in the Tvärminne Storfjärden, SW coast of Finland. Ophelia Suppl 4:101-110

Kivi K, Kaitala S, Kuosa H, Kuparinen J, Leskinen E, Lignell R, Marcussen B, Tamminen T (1993) Nutrient limitation and grazing control of Baltic plankton community during annual succession. Limnol Oceanogr 38:893-905

Kuosa H, Kivi K (1989) Bacteria and heterotrophic flagellates in the pelagic carbon cycle in the northern Baltic Sea. Mar Ecol Prog Ser 53:93-100

Kuuppo-Leinikki P, Autio R, Hällfors S, Kuosa H, Kuparinen J, Pajuniemi R (1994) Trophic interactions and carbon flow 
between picoplankton and protozoa in pelagic enclosures manipulated with nutrients and a top predator. Mar Ecol Prog Ser 107:89-102

Kuuppo P, Tamminen T, Voss M, Schulte U (2006) Nitrogenous discharges to the eastern Gulf of Finland, the Baltic Sea: elemental flows, stable isotope signatures, and their estuarine modification. J Mar Syst 63:191-208

Larsson U, Elmgren R, Wulff F (1985) Eutrophication and the Baltic Sea: causes and consequences. Ambio 14:10-14

Larsson U, Hajdu S, Walve J, Elmgren R (2001) Baltic Sea nitrogen fixation estimated from the summer increase in upper mixed layer total nitrogen. Limnol Oceanogr 46: $811-820$

Lignell R, Heiskanen AS, Kuosa H, Gundersen K, KuuppoLeinikki P, Pajuniemi R, Uitto A (1993) Fate of a phytoplankton spring bloom: sedimentation and carbon flow in the planktonic food web in the northern Baltic. Mar Ecol Prog Ser 94:239-252

Lohrenz SE, Fahnenstiel GL, Redalje DG, Lang GA, Dagg MJ, Whitledge TE, Dortch Q (1999) Nutrients, irradiance, and mixing as factors regulating primary production in coastal waters impacted by the Mississippi River plume. Cont Shelf Res 19:1113-1141

Mälkki P, Tamsalu R (1985) Physical features of the Baltic Sea. Finn Mar Res 252:1-110

Morris DP, Lewis WM (1988) Phytoplankton nutrient limitation in Colorado mountain lakes. Freshw Biol 20:315-327

National Research Council (2000) Clean coastal waters: understanding and reducing the effects of nutrient pollution. National Academy Press, Washington, DC

Nixon SW (1981) Remineralization and nutrient cycling in coastal marine ecosystems. In: Neilson BJ, Cronin LE (eds) Estuaries and nutrients. Humana Press, Clifton, NJ, p 111-138

Paasche E, Erga SR (1988) Phosphorus and nitrogen limitation of phytoplankton in the Inner Oslofjord (Norway). Sarsia 73:229-243

Pitkänen H, Tamminen T (1995) Nitrogen and phosphorus as production limiting factors in the estuarine waters of the eastern Gulf of Finland. Mar Ecol Prog Ser 129:283-294

Pitkänen H, Lehtoranta J, Räike A (2001) Internal nutrient fluxes counteract decreases in external load: the case of the estuarial eastern Gulf of Finland, Baltic Sea. Ambio 30: 195-201

Pollingher U, Berman T, Kaplan B, Scharf D (1988) Lake Kinneret phytoplankton: response to $\mathrm{N}$ and $\mathrm{P}$ enrichments in experiments and nature. Hydrobiologia 166:65-75

Redfield AC (1934) On the proportions of organic derivatives in sea water and their relation to the composition of plankton. Liverpool University Press, Liverpool, p 176-192

Redfield AC (1958) The biological control of chemical factors in the environment. Am Sci 46:205-221

Editorial responsibility: Otto Kinne (Editor-in-Chief) Oldendorf/Luhe, Germany
Ryther JH, Dunstan WM (1971) Nitrogen, phosphorus, and eutrophication in the coastal marine environment. Science 171:1008-1013

Schindler DW (1974) Eutrophication and recovery in experimental lakes: implications for lake management. Science 184:897-899

Schindler DW (1977) Evolution of phosphorus limitation in lakes. Science 195:260-262

Seitzinger SP (1988) Denitrification in freshwater and coastal marine ecosystems: ecological and economical significance. Limnol Oceanogr 33:702-724

Seitzinger SP, Kroeze C, Bouwman AF, Caraco N, Dentener F, Styles RV (2002) Global patterns of dissolved inorganic and particulate nitrogen inputs to coastal systems: recent conditions and future projections. Estuaries 25:640-655

Seppälä J, Tamminen T, Kaitala S (1999) Experimental evaluation of nutrient limitation of phytoplankton communities in the Gulf of Riga. J Mar Syst 23:107-126

Sterner RW (1994) Seasonal and spatial patterns in macroand micronutrient limitation in Joe Pool Lake, Texas. Limnol Oceanogr 39:535-550

Stålnacke P, Grimwall A, Sundblad K, Tonderski A (1999) Estimation of riverine loads of nitrogen and phosphorus to the Baltic Sea, 1970-1993. Environ Monit Assess 58: $173-200$

Tamminen T, Seppälä J (1999) Nutrient pools, transformations, ratios, and limitation in the Gulf of Riga, the Baltic Sea, during 4 successional stages. J Mar Syst 23:83-106

Thingstad TF, Krom MD, Mantoura RFC, Flaten GAF and 15 others (2005) Nature of phosphorus limitation in the ultraoligotrophic Eastern Mediterranean. Science 309: 1068-1071

Thomas H, Ittekkot V, Osterroth C, Schneider B (1999) Preferential recycling of nutrients - the ocean's way to increase new production and to pass nutrient limitation? Limnol Oceanogr 44:1999-2004

Tyrrell $\mathrm{T}$ (1999) The relative influences of nitrogen and phosphorus on oceanic primary production. Nature 400: 525-531

Vanni MJ, Temte J (1990) Seasonal patterns of grazing and nutrient limitation of phytoplankton in a eutrophic lake. Limnol Oceanogr 35:697-709

Vitousek PM, Howarth RW (1991) Nitrogen limitation on land and in the sea: How can it occur? Biogeochemistry 13: $87-115$

Vollenweider RA (1968) Scientific fundamentals of the eutrophication of lakes and flowing waters, with particular reference to nitrogen and phosphorus as factors in eutrophication. OECD Tech Rep DAS/CSI/68.27, Paris

Vollenweider RA (1976) Advances in defining critical loading levels of phosphorus in lake eutrophication. Mem Ist Ital Idrobiol 33:53-83

Submitted: January 30, 2006; Accepted: October 23, 2006

Proofs received from author(s): June 7, 2007 